\title{
Pakistan China relations in the Emerging Dynamics of Power in South Asia
}

Las relaciones entre Pakistán y China en la dinámica de poder emergente en el sur de Asia

Received: November 20, 2020

Accepted: March 11, 2021

\author{
Written by: \\ Ashraf Farzana \\ https://orcid.org/0000-0002-9213-9848 \\ Khalid Tanweer $^{2}$
}

\begin{abstract}
This research paper highlights and review the strategic relationship amongst Pakistan and China as emerging economic states and power balanced countries in South Asia. The region has always been in the news since many decades, starting from "Khyber Pass" which was a route to conquer the "Golden Bird", to the Union Jack, needs to trade for their economic resilience. The existence of Pakistan changes the dynamics of this region, as Pakistan is known as its strategic location which further helps the world in trade. The routes are key factual economic indicators for many countries, as sea routes for traders are enjoyed by the middle Eastern countries like United Arab Emirates, and Iran they mark accomplishments, not only in trade but in foreign relations also. Their strategic alliance and visionary leadership had made them the strongest country amongst all. Despite, they were dwelled in many tribal fights, which by the time made them learned to have their existence as United Republic of China. The main purpose of this research is to highlight and bring strategically importance geopolitical stance exercised by both the countries. We use qualitative research model to explore the reason of ties and through reviewed papers draft the conclusions to understand the value in this regard. The study found mutual benefit for both the countries and reveals the footprints of Sino-British relations amongst China and East India Company in midst of 1600 - 1640. Mao Zedong and Zhou En-Lai were the brains behind the revolution and strategic routes were devised to bring the economic stability for the Republic of China.
\end{abstract}

\section{Resumen}

Este artículo de investigación destaca y revisa la relación estratégica entre Pakistán y China como estados económicos emergentes y países con equilibrio de poder en el sur de Asia. La región siempre ha estado en las noticias desde hace muchas décadas, desde el "Paso Khyber", que era una ruta para conquistar el "Pájaro Dorado", hasta la Union Jack, que necesita cambiar por su capacidad de recuperación económica. La existencia de Pakistán cambia la dinámica de esta región, ya que Pakistán es conocido como su ubicación estratégica, lo que ayuda aún más al mundo en el comercio. Las rutas son indicadores económicos fácticos clave para muchos países, ya que las rutas marítimas para los comerciantes las disfrutan los países del Medio Oriente como los Emiratos Árabes Unidos e Irán marcan logros, no solo en el comercio sino también en las relaciones exteriores. Su alianza estratégica y liderazgo visionario los había convertido en el país más fuerte de todos. A pesar de ello, vivieron en muchas luchas tribales, lo que les hizo aprender a tener su existencia como República Unida de China. El objetivo principal de esta investigación es resaltar y traer la posición geopolítica de importancia estratégica ejercida por ambos países. Utilizamos el modelo de investigación cualitativa para explorar la razón de los vínculos y mediante artículos revisados redactamos las conclusiones para comprender el valor en este sentido. El estudio encontró un beneficio mutuo para ambos países y revela las huellas de las relaciones chinobritánicas entre China y la Compañía de las Indias Orientales entre 1600 y 1640. Mao Zedong y Zhou En-Lai fueron los cerebros detrás de la revolución y se diseñaron rutas estratégicas para traer la estabilidad económica para la República de China.

\footnotetext{
${ }^{1}$ Ph. D. Scholar, Preston University Karachi, Pakistan.

${ }^{2}$ Head of Department, International Relations, Preston University Karachi, Pakistan.
} 
Key Words: CPEC, Economic Stability, Regional Power and Trade, Infrastructure.

\section{Introduction}

Pakistan emergence on the globe was in 1947, inherited the legacy of Sino-British relations which were established between East India Company (1600) and the Manchurian Qing Dynasty in China (1644). The foremost objective of the British establishing relations with China was economic. Chinese porcelain, tea, and silk were the most sought commodities in Britain between 1720 and 1839 the East India Company was enough of resources i.e., silver to bear the burden of payment. Therefore, under the barter system, Indian Opium was shipped to China as the payment which adversely affected Chinese society. Despite the government's prohibition on the distribution of Opium in China in 1729, the sale of the product flourished which the British used as the "Cash Crop". An alarming rise in the number of addicts virtually rendered the government machinery inefficient.

However, subsequently, these relations turned out to be geostrategic after the fall of Napoleon in 1815; the British seized the moment and launched massive efforts to consolidate their possessions in Asia. Sheer differences in the Indian Opium trade and the British pursuit for domination in the region paved the way for the First Opium War (1839-1842).The opium was cultivated by East India Company was carried illegally to China for the revenue. The main objective of this venture was to counter the trade imbalance between the giant Britain and the depressive China. The Qing government of China once launched armed efforts to seize the British trade; hostilities between both empires broke out. The British royalty did not respond to the Chinese governments please on moral grounds to discontinue the smuggling of opium into China which was destroying generations of the Chinese population. After abortive diplomatic efforts, China resorted to military action against the British which prompted to retaliate militarily and force the Qing government which then signed the Treaty of Nanking in the late August of 18 century (Hoe \& Derek, 1999).This "Treaty of Unequal" terminates the Canton System based on equality and fairness which the British were unable to honor. East India Company created environments to lure China into an armed conflict in which the British were superior. The new Treaty produced a new mechanism which inflicted substantial loss to China with an agreement related to fixation of tariffs, the
Palabras clave: CPEC, estabilidad económica, energía y comercio regionales, infraestructura.

territory acceptance and accepting the nation as most favorite. The Chinese conceded this condition out of pragmatism and due to lack of knowledge of international law. Moreover, the Chinese did not understand the far-reaching consequences. At that time, China was a defeated nation. The 5\% tariff which was decided mutually was higher while the clause of extraterritoriality portrayed to put the weight on the Bruisers, while the point being most favored nation, sparks the relationship amongst the zone with others. China declares it, proved to be disadvantageous for China's in two aspects, the one Foreign Relations and the second one the Trade benefit. Concurrently, two developments were taking place in the region of South Asia; the First Anglo-Afghan War (1839-1842) and Colonization of Sindh (1843). Notably, the outcome of this Opium War (Anglo-Chinese War) was Britain's consolidation in South East Asia with the active support of the United States, Russia, and France (Tsang, 2007).

\section{China's initial territorial disputes}

Presently, a legacy of the Century of Humiliation impacts China's foreign policy which aims at regaining the status for itself when the nation was the pivot of East and South East Asia and smaller nations conformed to its hegemony. However, at that time, the geopolitical environments were different nations; more precisely tribal dominions, fiefdoms, and kingdoms considered China powerful and pretended to accede to its domination as a "Survival Strategy" while at the same time, continued their pursuance for a sustained dynastical rule under the congenial environment. The upper class or the elite dominated the entire socio-economic infrastructure of their dominion or kingdom. There was a natural alliance between the ruling class and the religious hierarchy in powersharing. Orthodoxy enforced Conservatism to ensure the elite's firm grip on the population. Pessimism rules the psyche of the Chinese people. Although the Century of Humiliation heralded an era of "Disgrace", this was the most spectacular phase in the history of China during which the elite's grapple loosened. Their myth of invincibility lost its value into chaos. The unholy alliance between rulers and clergy lost their impact among the general public. The atmosphere of recluse created by the lack of decision-making created a void that was filled by 


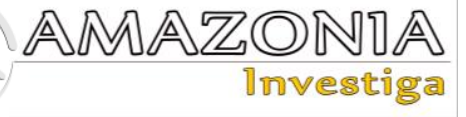

commoners. This was the decline of royalty which was being firmly strengthened by the clergy. The intra-societal power struggle turned violent leading to the Taipei Civil War in which Christianity was one of the adversaries. The anguish against the religious elements especially Christianity escalated beyond proportions. Hatred against foreigners, especially Britain, Japan, and the United States accelerated unprecedentedly among the nation when all working classes put up a united resistance against their elite as well as the foreigners. During the same period of "Humiliation", religion was replaced by Nationalism. It was the departure of royalty and traditional clergy. But the current Chinese leadership possesses a mindset of the "Regional Hegemony", a status which existed during the rule of royalty, indeed, a contradictory stance. China is poising to become one of the strongest states in the world. During this process, the Chinese intend to be assertive as a central authority, especially uncompromising on the religious issue like Islam which advocates its peculiar social code (Erie, 2016)

\section{Sino-Islam Relations}

Sino-Arabia links existed even before the advent of Islam in the Arabian Peninsula in the 7th Century AD. Yuan dynasty was the khanate that came into being after the division of Mongol Empire when a score of his tribesmen converted to Islam and, subsequently introduced it to mainland China which, at that time, was practicing Confucianism and Taoism. These religions (Islam, Confucianism, and Taoism) possess a substantial degree of similarities which facilitated the propagation in China. Primarily, it was the state of continuous contact between the people of the steppe of Central Asia and the Chinese population in the form of trade and armed conflicts which paved the way for the introduction of Islam. According to the documented history, one of the companions of Prophet Muhammad Sa'ad bin AbiWaqas was the first Muslim emissary representing the Third caliph Osman bin Affan who presented his credentials in the court of Emperor Gaozong of the Tang Dynasty in 651 AD. The fact remains that it was the Tang Dynasty (618-907) who's liberal and outward policies facilitated the spread of Islam in China.

\section{Sino-Pak relations \& South Asian politics}

A theory conceived by Sir Halford J. Mackinder, the geo-strategic location of Pakistan was impossible to ignore. Strategically, the geographical region situated at the confluence of the Middle East, South Asia and Central Asia which is called Pakistan served as the all-weather communication link among all countries. The proximity of Pakistan with relation to the Arabian Sea, the Strait of Hormuz and the Indian Ocean elevate its geographical position as one of the hubs of geopolitical connectivity/linkage in Asia. The most important advantage of having Pakistan into the fold of friendship is its location which interlinks Central Asia and entire West China with the Middle East, Europe, and Africa through the shortest possible land-maritime route (Singh, 2006). However, relationships in the international arena or otherwise are cemented by mutual respect and understanding. Sino-Pakistan relations are nothing but the collaboration of two great civilizations. Chairman Mao Zedong and Zhou En-lai, both pursued concerted diplomatic efforts to keep Pakistan engaged despite the dominant influence exercised by the US and the west over Pakistan during the Cold War Era. At that time, Pakistan under the fear of Indian aggression had tilted towards the west and, decided to conclude an agreement with the US against USSR which was feverishly pursuing the policy Communist expansionism worldwide. In this regard, the Chinese leadership comprehensively realized Pakistan's geostrategic compulsions amidst the influence of the US which was the standard-bearer of the west in the fiercest confrontation with Communism. Initially, it was USSR which was subsequently joined by China. Pakistan had the British colonial past and, formed an important part of the US Policy of Containment. Chairman Mao and his leadership were fully aware that Pakistan would not be able to take independent decisions aimed at developing cordial relations with China. However, the fact remains that whenever Pakistan was in distress and, the US and its western allies displayed reluctance to assist, China's unconditional rescue effort won the public confidence. This notion concerning China as a dependable ally peaked during the IndoPakistan War 1965 when the US and its allies imposed an embargo on Pakistan. But, despite USSR's inclination towards India while China, also in alliance with Moscow, extended unprecedented moral, diplomatic and material support to Pakistan. This development proved that China can take independent decisions that are in their best interests, but in the meantime, the Chinese leadership is credible concerning their commitments which they hounded reluctance. In this regard, Pakistan's western allies in addition to the number of Muslim states from anti-US bloc sided with India. Realistically, China's role in establishing cordial Sino-Pakistan relations is unequal. The most historical development was 
the dissolution of the Sino-Pakistan border dispute which was signed in March 1963. This agreement tilted the balance of power in the Cold War scenario in South Asia in China's favor which earned annoyance from the US and its allies. But it was the beginning of a new phase in their relations. Pakistan managed to secure the friendship of a trusted neighbor which was able to assist Pakistan in its difficult times. Total reliance on the US and its allies diminished which meant that the era of exploitation of Pakistan at the hands of western powers was over. It is important to mention that since the conclusion of the Sino-Pakistan Border Agreement, their relations have excelled over time despite malicious attempts by their hidden adversaries. In this context, the western media has always been averse to China's shocking trajectory in every field of life. While Pakistan is always portrayed as a state of "Bigoted Fanatics" which poses an existential threat to western civilization, certainly less than an exaggeration. This is an undeniable fact that the soil of Pakistan has always been used by the US and its allies against USSR, Iran, and Afghanistan.

However, China was also troubled when terrorist elements in the Xinjiang Province of China were assisted by Pakistani soil whose authenticated proofs were shared by the Government of China with Pakistani authorities. This scenario adversely affected their relations. Since China was fully aware of this conspiracy hatched by the western powers in which Pakistan was being used as an instrument. Relation took another turn. Both countries decided to uproot terrorism through a meticulously planned and executed counter-terrorism campaign. It is appropriate to comment that Pakistan is one of those states which played an eminent role in eliminating China's isolation planned by the west. India was one of the first countries which recognized China and, extended its hand of friendship but Prime Minister Nehru's dream could not be materialized. The relations were stalled due to the inter-state border dispute which ultimately led to the Indo-China War in 1962. The unfolding of this geostrategic scenario facilitated the western power involvement in South Asia which, ultimately led to the escalation of the Cold War in the 1960s. The US inclination towards India which was initially discreet due to Prime Minister Nehru's priority towards the USSR and its allies perturbed Pakistan whose foreign policy was India-centric based on flawed perception injected by constricted minds of early leadership which were hostage to the British colonial mindset. The same era heralded the beginning of an unstoppable armed race, the nuclearization of
South Asia and, persistent state of hostility in South Asia. These environments were the main cause that pushed Indo-Pakistan War in 1965 followed by another in 1971 which secured independence for the Bengali community in the East Bengal; Bangladesh. During these two wars, China remained at a safe distance concerning its involvement in terms of men and material. However, it extended wholehearted diplomatic support to Pakistan at every forum including the United Nations. However, the fact remains that China has always been a well-trusted ally of Pakistan in all-weather environments.

\section{Pak-China bilateral cooperation (CPEC)}

Global governmental issues are seeing another time of reliance and territorial network. With this a solid challenge among states has started and uncommon relationship has incited exceptional collusion arrangements and local reconciliation for creating territorial economies and keeping up provincial harmony. Local security and monetary exercises have become different sides of a same coin in Asian states. Exercises to improve provincial monetary participation along with arrangement of political and financial coalitions are expanding in Asia because of recently propelled ventures of China. New vistas of financial combination are showing up because of China's One Belt One Road activity. CPEC being a significant part of OBOR complemented Pakistan's territorial significance since it appreciates extraordinary topographical favorable circumstances in the South Asia. Being at the point of South Asia, Central Asia, China and Persian Gulf, "Pakistan's geo-monetary significance comes from its area at the intersection." (Lodhi, 2009).

Surmounting issues, for example, vitality emergency, fear-based subjugation and absence of appropriate vehicle frameworks are reducing monetary exercises of Pakistan. Regardless of entire reservations, the jobs in Pakistan as a local connector have persuaded that Pakistan's nearby participation with Central Asia is vital as CPEC offers stages for CARs to coordinate Chinese geopolitical and monetary destinations (Afzaal, 2016). The geo-financial advantages of CPEC for China and Pakistan, its beneficial outcomes on CARs are being thought. In any case, hypothetical highlights are underscored trailed by its application while proposals are additionally given. 


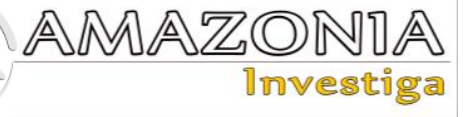

Significance of CPEC

CPEC is being foreseen as a provincial distinct advantage which will be useful for the territorial nations because of its overflow impact. It purposes to associate other neighboring nations for infra-structural advancements, business, and exchange promptness financial improvement and development. Pakistan tries to expand its exchange action, associate its industry through vitality framework and correspondence or more all structure mechanical zones and Gwadar Port (Amir, 2016). Furthermore, CPEC is an extraordinary leeway for Pakistan with respect to monetary speculation proposed at empowering its financial system; more than as it will be an advantage which may give badly wanted evenness in opposition to reinforcing India's vital and financial entrance within South Asia. It is generally confronting the ominous circumstance as Karakoram Highway (China Pakistan Friendship roadway) is associating China and Pakistan not withstanding India's entrance to Central Asia. Sarah Watson, a specialist on Indian issues said that Pakistan and China participation can represent a military test to India as well as influence its entrance to rewarding exchange courses (Abbasi, 2016). CPEC fills in as the briefest exchange course for China to Arabian Sea and afterward interfacing in to West Asia and Europe bypassing the chock point of Malacca. Consequently, provincial network is delivering new-fangled roads of participation for landlocked states including Uzbekistan, Afghanistan, Tajikistan and Turkmenistan. This wonder is all about clarified in a hypothetical example of neo-functionalism (Mitrany, 1966) which seats accentuation on the job of a nation and non-governmental entertainers in local mix; it likewise exhibits the chance of auxiliary incorporation between nations. The overflow would absorb CARs in monetary domain along with exchange openings would prompt combination in different parts, for example, social and social spaces. Besides areas of Central Asia, South Asia and Middle East are relied upon to harvest colossal financial profits from the Corridor. South Asian district is viewed as an exceptionally broken locale considering the expanding populace, battling economies, vitality lack, radicalism, militancy, psychological oppression and water shortage. South Asian locale is likewise segmented at all financially incorporated zones on the planet, while different districts of globe have higher in between provinces exchange. South Asian intra-territorial exchange is simply 3-5 percent of the absolute exchange of the locale, exhibiting simply over 1 percent of provincial GDP while it is $7 \%$ in East
Asia. Simply India is exchanging with neighbors in fewer than 3\%. (Ahmed, 2015). Similarly Central Asia is likewise confronting extreme monetary, political and security challenges (Siviter, 2016), albeit not quite the same as South Asia, however bringing about dilemmas are normal. Autos are landlocked because of which monetary improvement has gotten emotionless, and their security issues are profoundly individualized (Tenrisever, 2013). Even though Central Asia, holding affluent in soil assets such as crude oil, gas, Uranium and further more raw materials because of the detachment of direct marine, the tracking down of partners to connect to global marketplaces pursue on. In the current circumstances Gwadar port presages opulence for CARs and radiates optimistic consequences on local amalgamation ventures. China the large size economy of the world (Chow, 2012) efficiently follows its authority in the area to diminish tensions; it is thought that collaborative business, manufacturing growth along with communications can carry success for each and every one. China is concerned regarding the safety of its fringe and expects to fabricate gracious associations with CARs (Petersen and Barysch, 2011).

China and Pakistan in a parallel way, locate the stipulations of CPEC those will inevitably conclude the track in addition to degree of succeeding constructive transformation. Pakistan's geo-premeditated position exhibits it as a crucial nation and it provides as a expected association of the affiliates of TAPI, CPEC, CASA-1000 along with Shanghai Cooperation Organization (SCO). Its tactical position is building it important, for South Asia, Central Asia, and West Asia. Pakistan and China distribute a boundary and this geological immediacy connecting both the nations to make their connections sturdier. China furthermore has ecological linkages in addition to brawny ties along with CARS in stipulations of business and safety, which is admirable to give way prosperity. However, non-coastal CARs are open to the elements of grave monetary tribulations that looking for a collaborator, further than Russia, to offer them feasible cours (Azizian \& Zhang, 1998). A vociferous issue directs CARs close to China and Pakistan is a practicable substitute for CARs (MacDonald, 2003).Uniformly, Central Asia's massive oil and gas possessions may be consumed in gratifying the power requirements of Pakistan. In CARs can make use of Gwadar port to sell abroad their products in the global markets. Just the once this itinerary develops into accessible for business, further business sites that are adjacent to this 
course will also be reachable and financial corporation will breed. Furthermore, Pakistan will have the opportunities to improve its premeditated significance to perform like a viaduct in-between Asian and African regions by the execution of CPEC which joins South Asia and Central Asia. Consequently, CPEC is a life span expansion prospect for Pakistan. The Gwadar Port, at the same time as attaining substance as Pakistan's trade and industry hub, will be one of the most imperative harbors in Arabian Sea. The financial and power collaboration among other areas will have an overflow consequence and it will pledge a profitable for all position. (Lim, Chan, Tseng \& Lim, 2016).

\section{Dimensions of Pak-China relations \& implications}

\section{Pakistan China Economic Relations}

Both the countries appreciate perfect relationships in a bondage with trust and credibility, further they continued relationship advances with the government high and low tides as circumstance, however it gets more grounded and more profound. It is essential for the two nations to watch out for the new and fast changes in provincial and worldwide advancements and outcome an appropriate system to address the difficulties. Solid measures to confront the local circumstance and security of the two nations are of grave significance. Both the countries are in the area that has incredible geological significance and is concerned with practically $50 \%$ of the total populace as the large of the population is being shared by China. The territory is stacked with skilled human resources and specific assets. Geological significance of this area is unquestionable and progressively vital as Russia, has its inclinations in the locale considering Central Asian states' being quick to the district in terms of energy, constructions, and technological advancements.

One of the acclaimed articulation of Chinese Premier Li Keqiang, (Syed \& Jamali, 2019), On the off chance that "you love China, Love Pakistan as well." These announcements are the structure obstructs as well as the demonstrated real factors of the wonders of time between the two nations. More than 60 years of genial relations, the profundity has heightened increasingly keeping in see changing universal stages from the worldwide war on dread to other significant global occasions onwards. China demonstrated her all prepared fellowship dependent on fairness and shared regard and congruity. The elevated level talks and solicitations to dignitaries make a helpful environment for the respective relationship. Pakistan and China need each other in the field of economy, vital partnerships, and military joint endeavors as both are atomic force nations and understudy trade projects to additionally fortify the ties in the progression of science and innovation and a lot more parts of life.

The region under the influence face problems, concerning the security issues, as Pakistan faces the common border with four major stakeholders in the same. The Central Asia's biggest problem is the Afghanistan lingering issues with the major player Chain and Pakistan. On the other side the Kashmir issue has been raised to the point of no return the states instability due to their political structure and their hegemonic designs is getting the advantage to get the status quo for the same. The big problem is Afghanistan in the region involved in the war since many decades; the war is more likely is the unresolved issue. Despite the fact that nation was by then included internal strife and struggle during '70s, straight assault by the now- archaic Soviet Union in 1979 irritated the location for the country itself and its neighbors and the whole world. Massive restriction advancement against the Soviet occupation and overall weight made in expelling of Soviet from Afghanistan during 1989-90, yet war-assaulted nation was left isolated. Blemished extraction plan, hindrance in the track of action of a wide supported compromised government in Afghanistan, and general system's lack of approachability to the multifaceted idea of Afghans incited expansive political tumult and scatter and the people who had paid war against an occupation power, sold out one another in an idea to develop have writ in a country with no bit of amicability and rule of law. Feeling compelled to secure their tendencies, neighboring countries furthermore occupied with the contention. Undoubtedly, even now, when a collusion government exists there with the help of the worldwide association since the fall of the Taliban framework (Mashal, 2019) in December 2001, wrangling is continuing - in one structure or the other. Central Asia is an eccentric locale; overall powers have reliably been pulled in by trademark and resources in Central Asia, further the degree of impact during the Cold War constrained concordance in this area and that affected an immense factor behind Afghan capture. Kashmir issue has been a critical point of dispute among Pakistan and India since their independence in 1947. The two nations faced wars against each other, for achieving the benefit 


\section{AMAZONIA
Investiga}

of confidence, which was being finished smoothly in the political field.

\section{Expanding collaboration and impact on the region}

Chinese assistance extends from trade to Agriculture sector and commerce to defense also, improvement in the energy sector also helps Pakistan to grow and can reform its infrastructures positively for the betterment of the nation in the long run. The changing global attitude in term of environment or bilateral resolutions, are strengthening their bondage more which includes rapid growth in general. China, with its speedy paced and continuous fiscal expansion, is balanced to participate more as concrete character in the global market from now and beyond. It is conventional to become world's biggest financial system on acquiring energy equivalence center in 2015. It will also become a chief participant in global market as a most important abroad seller and objective hub of imports. Its global incarceration is probable to persist while there will be a change from aspect ambitious aggressiveness to knowledge obsessed and modernization determined. Pakistan will stay in the factor-driven group for some more years still to come. This will also progress the capacity of cooperation through inter-manufacturing bonds and joint endeavors. The worldwide, area wise and state realism should emphasize upcoming hard work of assistance. These proceedings should be a foundation of potency for ornamental jointly advantageous support (Khan, 2004).

\section{Methodology}

The use of secondary data helps to complete the study which refers to the qualitative analysis that further explains the possibilities in region to further explore the dynamics of power. This research explores the avenues of relations of Pakistan with China in context to South Asia geo-political stance and analyzes the upcoming strategies for the benefiting locally as well as globally

\section{Results and discussion}

The study unfolds the facts regarding CPEC and China's relations specifically in the region and with the intercontinental strategic associations. Through the conclusions, China with its fullest of the energy in the sector of Human Resources, Infrastructure, Technological, and Nuclear armory wants to become the Economic Superpower. The facts highlight, that they want the world to be with them. Pakistan is strategically strong in relationship due to many factors, amongst which few are;

a. Geographical location (Borders and Routes)

b. The deep sea Ports

c. Best being Ally

d. Nuclear Power

e. Trustworthy

f. Friendly

The factors support Pakistan to be the most reliable partners, but strategist must think on mutual benefits enjoyed by both the countries. Though some reservations were addressed at the level of foreign ministry and armed forces, but importance was given to CPEC which is provided full support for working it viable for the region as well as China. Pakistan has the tendency to neutralize the situation as a key strategic partner and has helps several countries in their difficult times. The CPEC will be the Golden Route for the region and the deep-water port is one of its own kinds, a game changer. Pakistan should make efforts to bring Chinese language more common for understanding of their culture and norms of doing businesses. This would help to have effective communication between the countries. Pakistan must give priorities to the locals in the Baluchistan to have their confidence in line with the security and safety of the project also. On the other side Baluchistan being deprived, will get a transformational affect in its economy, infrastructure, and education overall will help in gaining trust of the local population.

Pakistan can play a mediating role for China in building up the trade relationship with the countries of Middle East, Iran and Afghanistan. Regional stability will primarily depend upon peace in Afghanistan which would lead to a safe and secure route to be profitable. The country and management should look for providing capacity building measures. India being the second biggest economic power in the region and having multiple reservations with the CPEC, can be neutralized with effective mutual policies of Pakistan and China in bringing parallel trade ties for the betterment of bordering states. Last but not the least; Pakistan's diplomatic ties must be in line with the wishes of the people of Pakistan for many decades have sacrificed their lives in bringing peace in the region. The agreement must be accessible to the parliament and common man, who can determine their value in against what we have awarded to the Chinese and their government in bringing them as economic regional power. 


\section{Conclusions}

China is not only a country to be named, it is a vision by capacity and a milestone to be achieved in economy and trade and transformation from the pine era to the highly digitalized economic reform one. The efforts cover decades but creation of nation always depends on a visionary leadership such as Mao Zedong, Chairman and the Founding Father of Peoples' Republic of China. October 1, 1949 brought the day for a new revolution after many dynasties. The relation with Pakistan is reflection of Sino British relations, which empowers China as an economically revolutionized country. Chinese leadership then through their leadership and strategic vision curtailed the impact of opium war leading to the decline of progress. China is the country which marked its success through hard work and resilient approach in making things better by boosting their nation. The essence of these stories depends on Chinese history which is straightforwardly identified with its relations with the neighboring states. This is certifiably not a kind marvel of admiring itself being a geopolitical force.

Sino-Pakistan relations are only the cooperation of two incredible human advancements. Administrator Mao Zedong and Zhou En-lai, both sought after purposeful political endeavors to keep Pakistan drew despite the predominant impact practiced by the US and the west over Pakistan during the Cold War Era. Around then, Pakistan under the dread of Indian hostility had tilted towards the west and chose to finish up a concurrence with the US against USSR which was hotly seeking after the strategy Communist expansionism around the world. The most verifiable advancement was disintegration of the Sino-Pakistan fringe contest which was marked in March 1963. This understanding tilted the level of influence vulnerable war situation in South Asia in support of China which earned disturbance from the US and its partners. Pakistan figured out how to make sure about the kinship of a confided in neighbor which was in a situation to help Pakistan in its troublesome occasions. All out dependence on the US and its partners lessened which implied that the time of misuse of Pakistan on account of western forces was finished. It is essential to refer to that since the finish of the Sino-Pakistan Border Agreement and their relations have exceeded expectations with the progression of time despite malignant endeavors by their concealed enemies. Right now, western media has consistently been loath to China's stunning direction in each field of life.
By 1991 the foreign trade of China was 166 Billion (in dollars) and became the most powerful trading country in the world. Their growth totally is due to the job expansions and generation of new avenues for their upcoming youth entering the industry each year. The industrial and agricultural reforms in the form of good management decisions and governance paid them back. The risen output yield and thorough policies supports them to be the best in the region and specifically in the world. The factor globalization has taken China's economy to sky high; initially $4.5 \%$ of growth impact is measured in the early years of reforms. The change in politics after 1978 brought drastic revolution and economic modernization. The only party rules and devised the policies and after 1990 the privatization was another step towards the beginning of new era.

Going Global is the motto from the nation, which helps them to promote and open the doors for the foreign trade and investments to their economic growth. The era from 2005-17 supports the middle-income economies in getting rise to $83 \%$ of constructional projects. that's not the only sector they gain, banking, transportation, information technology, science, medical, and many more areas, in which their positive stance of building relationships guard their growth and helped them to be economic tigers. China has invested almost in every country in the globe for the better relations, in western Asia, China has a priority in the area of energy security, due which the Zuhai port holdings invests 1.62 Billion (in dollars) in Gwadar port as the first project on the One Belt One Road (OBOR) initiative. Pakistan and China enjoy the brotherly relationship with consummate responsive ties at all levels. Being in the region have strong bondage of trust with a population strength count over 2 billion. The region has abundance of human and natural resources.

At last, China is the solution provider and the strength of Pakistan in providing the and developing the infrastructure specifically in the Baluchistan region, by giving support to rebuild the land appropriate for the youth of the said region. The government and the Army have taken a stance to guard the CPEC for the betterment of Pakistan to stabilize the situation in the areas of economy as well as infrastructure developments.

\section{References}

Abbasi, A. (2016). CPEC has changed Economic Outlook of Pakistan, S. Asia. (December 03), 


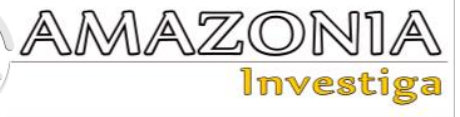

The

News,

Islamabad.

https://www.thenews.com.pk/print/169458-

CPEC-has-changed-economic-outlook-of-

Pakistan-S-Asia

Afzaal, M.O (2016). Why CPEC Mattersto the

World: Delivering Security Through Economic

Development. Centre for Strategic and Contemporary Research. Retrieved from https://cscr.pk/explore/themes/trade-

economics/cpec-matters-world-delivering-

security-economic-development/

Ahmed, Z. (2015). China Pakistan Economic Corridor: A Gateway to Regional Economic integration. South Asian Voices, accessed 1stDecember, http://southasianvoices.org

Amir, F. (2016). CPEC and Regional Integration. Paper presented at the 32nd Annual General Meeting and Conference of the PSDE on ChinaPakistan Economic Corridor and Regional Integration. Pakistan Institute of Development Economics, Islamabad Islamabad. http://www.pide.org.pk/psde/pdf/papers/AGM3 2/PSDECall-for-Paper.pdf

Azizian, R., \& Zhang, Y. (1998). Ethnic Challenges Beyond Borders: Chinese and Russian Perspectives of the Central Asian Conundrum. New York: St. Martin Press, 43.

Chow, G.C (2012). China as a Leader of the

World Economy. New Jersey: Princeton University, 4.

Erie, M.S (2016). China and Islam, The Prophet, the Party, and Law. Cambridge: Cambridge Studies of Law and Society.

Hoe, S., \& Derek, R. (1999). The Taking of Hong Kong Charles and Clara Ibid. Londres: Routledge, 316 Pages.

Khan, B. A. (2004). China-Pakistan to Strengthen Defence Ties. Dawn. https://www.dawn.com/news/377354/chinapakistan-to-strengthen-defence-ties Lim, T W., Chan, H.H.L., Tseng, K., \& Lim, W.X. (2016). China's One Belt One Road Initiative. London: Imperial College Press, 286. Lodhi, I.A. (2009). Pakistan's Energy and Geopolitics, the Geopolitics of Energy in South Asia. Singapore: Institute of South Asian Studies, Marie Lall ed, pp 98.

MacDonald, J.A. (2003). Rethinking India's and Pakistan's Regional Intent. NBR Analysis, Vol 14(4), 24.

Mashal, M. (2019). U.S. and Taliban Agree in Principle to Peace Framework, Envoy Says. The New York Times. https://www.nytimes.com/2019/01/28/world/asi a/taliban-peace-deal-afghanistan.html

Mitrany, D. (1966). A Working Peace System. Chicago: Quadrangle Books, 28.

Petersen, A. \& Barysch, K. (2011). Russia, China and the Geopolitics of Energy in Central Asia. Centre for European Reform, 39.

Singh, M. (2006). Pakistan's Strategies in Central Asia. Strategic Affairs. Vol 30, Issue 4.

Siviter, N. (2016). Emerging Challenges in Central Asia. NAOC. http://natoassociation.ca/emerging- challengesin-central-asia/

Syed, A., \& Jamali, A. B. (2019). Pakistan-China Relations in the 21st Century. Moderndiplomacy.

https://moderndiplomacy.eu/2019/01/05/pakista n-china-relations-in-the-21st-century/

Tanrisever, O.F. (2013). Afghanistan and Central Asia: NATO's Role in Regional Security since 9/11. Netherlands: IOS Press, 86.

Tsang, S. (2007). A Modern History of Hong Kong. London: I.B. Tauris. pp. 3-13, 29. 